\title{
Building Effective Communication Between Teachers and Early Children In PAUD Institutions
}

\author{
Ditha Prasanti ${ }^{1}$, Dinda Rakhma Fitriani ${ }^{2}$ \\ Program Studi Ilmu Komunikasi, Fakultas Ilmu Komunikasi Universitas Padjadjaran
}

\begin{abstract}
Effective communication is certainly the dream of everyone who does it. Not separated from the communication process, early childhood also interacts to achieve the desired communication goals. In this article, the author discusses the efforts to build effective communication for teachers and early childhood in the X PAUD institution in Bandung. The author sees this topic as very important because it is an urgency now to express the creation of effective communication between teachers and early childhood in their PAUD institutions. This study uses a qualitative approach to the case study method. The author raises a case about efforts to build effective communication in the PAUD X institution. This study is very suitable to be analyzed with symbolic interaction theory because there is a meaning in the communication process conducted by teachers with early childhood in the PAUD institution. The results showed that there were efforts made to build effective communication between teachers and early childhood, including: (1) PAUD teachers as communicators must have characteristics of patience, willingness to sacrifice, attention, assertiveness, and be able to attract early childhood attention; (2) the existence of media / tools used by PAUD teachers at the $\mathrm{X}$ institution to achieve effective communication for teachers and early childhood; (3) PAUD teachers must understand the diverse character of their students.
\end{abstract}

Keywords: Building, Effective Communication, Teachers, Early Childhood

\begin{abstract}
Abstrak
Dalam artikel ini, penulis membahas tentang upaya membangun komunikasi yang efektif bagi guru dan anak usia dini di lembaga PAUD X yang berada di Bandung. Penulis melihat topik ini sangat penting karena menjadi urgensitas saat ini untuk mengungkapkan terciptanya komunikasi yang efektif antara guru dan anak usia dini di lembaga PAUD nya. Penelitian ini menggunakan pendekatan kualitatif dengan metode studi kasus. Penulis mengangkat sebuah kasus tentang upaya membangun komunikasi yang efektif di lembaga PAUD X. Kajian ini sangat cocok dianalisis dengan teori interaksi simbolik karena terjadi pemaknaan dalam proses komunikasi yang dilakukan guru dengan anak usia dini di lembaga PAUD tersebut. Hasil penelitian menunjukkan bahwa adanya upaya yang dilakukan dalam membangun komunikasi efektif antara guru dan anak usia dini, meliputi: (1) guru PAUD sebagai komunikator harus memiliki karakteristik sabar, rela berkorban, perhatian, tegas, serta mampu menarik atensi anak usia dini; (2) adanya media/ alat yang digunakan guru PAUD di lembaga X tersebut untuk mencapai komunikasi efektif bagi guru dan anak usia dini; (3) guru PAUD harus memahami karakter murid-muridnya yang beragam.
\end{abstract}

Kata Kunci : Membangun, Komunikasi Efektif, Guru, Anak Usia Dini

@ Jurnal Obsesi Prodi PG-PAUD FIP UPTT 2018

$\triangle$ Corresponding author :

Address : J1.Raya Jatinangor - Sumedang KM.21 Bandung

Email : dithaprasanti@gmail.com 


\section{PENDAHULUAN}

"We can not not communicate...", merupakan salah satu point dalam prinsip komunikasi yang dicetuskan oleh Mulyana dalam bukunya "Pengantar Ilmu Komunikasi". Penulis teringat istilah tersebut karena menandakan bahwa manusia memang tidak dapat menghindari komunikasi, "kita tidak dapat tidak berkomunikasi". Hal tersebut menjelaskan betapa pentingnya komunikasi dalam setiap aspek kehidupan manusia. Tak mengenal usia, anak-anak, remaja, dewasa, semuanya membutuhkan satu kata yang bernama "komunikasi" (Mulyana, 2010).

Dalam artikel penelitian ini, penulis sangat tertarik mengungkapkan kajian komunikasi anak usia dini. Penelitian ini bermula dari perhatian penulis tentang pola komunikasi yang dilakukan guru dengan muridnya, notabene sebagai bagian anak usia dini, di lembaga Pendidikan Anak Usia Dini (PAUD). Pada dasarnya, setiap kalangan, baik tua maupun muda, siapapun orangnya, tentu menghendaki tujuan komunikasinya tercapai. Lalu bagaimana dengan para guru PAUD yang berkomunikasi dengan murid-muridnya, yang tergolong kategori anak usia dini? Ini merupakan topik yang menarik untuk diungkapkan.

Penelitian yang dilakukan oleh Aulina (2018) tentang motivasi belajar anak usia dini. Dalam hasil risetnya, Aulina (2018) menggambarkan penerapan metode Whole Brain Teaching dapat meningkatkan motivasi belajar anak usia dini. Penerapan metode whole brain teaching tersebut dilaksanakan melalui tujuh prinsip yakni : a) Seruan sapa guru terhadap kelas (Class-Yes), b) Mengajar sambil melakukan gerakan-gerakan simbolik bermakna (Gestures), c) Saling mengajar antaranak (Teach - Ok), d) Menirukan Gesture dan penjelasan guru (Mirror), e) Mengajar teman secara bergantian (switch-ok), f) Pemberian skor penilaian terhadap partisipasi anak dalam pembelajaran (Scoreboard), g) Memeriksa pemahaman anak atas materi pagi (comprehession check)(Aulina, 2018).
Selain motivasi belajar anak usia dini, penulis juga menemukan kajian lain yang membahas tentang anak usia dini. Aprinawati (2017) menggambarkan bahwa penggunaan media gambar dapat membantu perkembangan kemampuan berbicara anak usia dini. Media gambar seri memiliki suatu urutan gambar sehingga dapat merangsang pikiran anak untuk berbicara dan menghasilkan cerita yang berkesinambungan. Hasil penelitian diperoleh dengan menggunakan media gambar seri dapat mengembangkan potensi perkembangan berbicara anak dan menambah penguasaan kosakata yang dimiliki anak usia dini tersebut (Aprinawati, 2017).

Jika melihat kedua penelitian di atas, ada kesamaan objek yang menjadi sorotan utama yaitu anak usia dini. Kajian anak usia dini sangat menarik untuk dibahas dari berbagai macam perspektif, seperti halnya Aulina (2018) yang mengungkapkan tentang motivasi belajar anak usia dini, serta Aprinawati (2017) yang berbicara tentang pentingnya penggunaan media gambar dalam melatih kemampuan berbicara bagi anak usia dini.

Berbeda dengan penelitian terdahulu di atas, penulis melihat ada aspek penting lainnya yang perlu diungkapkan, yaitu tentang upaya membangun komunikasi efektif yang dilakukan guru kepada anak usia dini sebagai muridnya di lembaga PAUD. Komunikasi yang efektif tentu menjadi impian setiap orang yang melakukannya. Tak lepas dari proses komunikasi, anak usia dini pun melakukan interaksi untuk mencapai tujuan komunikasi yang diinginkannya.

Urgensitas penelitian ini adalah untuk mengetahui upaya membangun komunikasi yang efektif antara guru dengan anak usia dini sebagai muridnya di lembaga PAUD. Aspek komunikasi merupakan point utama dalam interaksi yang terjalin antara guru dengan muridnya, oleh karena itu perlu diungkapkan sehingga memperkaya khasanah keilmuan tentang kajian anak usia dini. 
264 Improvement of the Logical Intelligence Through Media Kolak

Dalam artikel ini, penulis membahas tentang upaya membangun komunikasi yang efektif bagi guru dan anak usia dini di lembaga PAUD $X$ yang berada di Bandung. Penulis melihat topik ini sangat penting karena menjadi urgensitas saat ini untuk mengungkapkan terciptanya komunikasi yang efektif antara guru dan anak usia dini di lembaga PAUD nya. Penelitian ini menggunakan pendekatan kualitatif dengan metode studi kasus. Penulis mengangkat sebuah kasus tentang upaya membangun komunikasi yang efektif di lembaga PAUD X. Kajian ini juga relevan jika dianalisis dengan teori interaksi simbolik, karena terjadi pemaknaan dalam proses komunikasi yang dilakukan guru dengan anak usia dini di lembaga PAUD tersebut.

\section{Proses Komunikasi}

Jika melihat beberapa literatur mengenai komunikasi, penulis teringat bahwa komunikasi merupakan proses, ada elemen-elemen yang terkandung di dalamnya, sehingga komunikasi tersebut dikatakan sebagai sebuah proses. Proses komunikasi dapat dikatakan sebuah tahapan komunikator dalam menyampaikan pesan kepada komunikannya, sehingga dapat menciptakan suatu persamaan makna antara komunikan dengan komunikatornya. Proses inilah yang dinamakan menciptakan komunikasi yang efektif.

Adapun unsur atau elemen yang terkandung dalam proses komunikasi, sebagaimana paradigma Laswell mengatakan bahwa cara yang baik untuk menjelaskan komunikasi ialah menjawab pertanyaan Who say what in which channel to whom with what effect? Artinya, komunikasi adalah proses penyampaian pesan oleh komunikator kepada komunikan melalui media yang menimbulkan efek tertentu (Mulyana, 2010).

Jika merujuk pada definisi di atas, maka unsur komunikasi terbagi menjadi komunikator, pesan, media, komunikan, dan efek. Unsur tersebutlah yang akan membentuk komunikasi yang efektif, jika pada dasarnya hasil akhirnya nanti mencapai kesamaan makna antara komunikator dan komunikan.

\section{Konsep Anak Usia Dini}

Prasanti \& Fitriani telah mengungkapkan tentang pembentukan karakter anak usia dini yang terjadi mulai dari keluarga, sekolah, dan perkumpulan bermain yang diikutinya yaitu komunitas. Pada dasarnya, perkembangan karakter anak usia dini dimulai dari lingkungan pertamanya, tak lain adalah keluarganya. Setelah itu, ketika anak usia dini tersebut masuk dalam lingkungan sekolah dan kelompok bermainnya, maka ada beberapa faktor juga yang akan mempengaruhi karakter anak usia dini tersebut (Prasanti \& Fitriani, 2018).

Pada dasarnya, penelitian di atas memperlihatkan konsep anak usia dini dari sudut pandang yang berbeda. Karakter anak usia dini dan citra anak tentu akan terbentuk dengan pondasi pendidikan yang baik dan benar. Sebagaimana diungkapkan Frobel yang memandang aspek pendidikan sebagai point penting bagi anak usia dini. Menurutnya, pendidikan bagi anak merupakan pengembangan autoaktivitas, yaitu aktivitas yang mendorong anak untuk aktif dan produktif serta diberikan kesempatan untuk tumbuh dan berkembang (Yus, 2011).

Hal tersebut penting diketahui para orangtua khususnya, agar dapat mendukung terlaksananya pendidikan dan karakter anak usia dini yang baik. Oleh karena itu, penulis merasa tertarik untuk mengangkat tentang upaya dalam membangun komunikasi efektif antara guru dengan anak usia dini sebagai muridnya.

Disamping itu dalam komunikasi peran kata-kata sangat penting. (White, Peter, \& Redder, 2015) dalam penelitiannya menyatakan "words alone held the least potential for reciprocal dialogue over all types of language exchange". 


\section{METODE PENELITIAN}

Dalam penelitian ini, penulis menggunakan pendekatan kualitatif dengan metode studi kasus. Menurut Creswell, kasus itu sendiri adalah sesuatu yang dipandang sebagai suatu sistem kesatuan yang menyeluruh, tetapi terbatasi oleh kerangka konteks tertentu. Kasus atau isu atau masalah yang harus dipelajari, akan mengungkapkan pemahaman mendalam tentang kasus tersebut, sebagai sebuah sistem yang dibatasi, serta melibatkan pemahaman dari peristiwa, aktivitas, proses bagi satu atau lebih individu tertentu yang berhubungan dengan topik penelitian tersebut (Creswell, 2010).

Melalui penelitian studi kasus, penelitian dapat diungkapkan secara deksriptif tentang fokus penelitian tersebut. Penulis pun menggunakan teknik pengumpulan data yaitu wawancara, observasi non partisipan, dan studi literatur.

Adapun informan yang digunakan dalam penelitian ini diambil sesuai dengan kebutuhan penelitian. Penulis memilih informan yang sesuai kriteria penelitian, yaitu para guru aktif dan senior di lembaga PAUD $X$, sehingga diperoleh 4 orang informan sebagai berikut:

1.ND, guru senior lembaga PAUD X 2.DR, guru senior lembaga PAUD $X$ X

3.LN, guru kelas A lembaga PAUD

4.NF, guru kelas B lembaga PAUD X

\section{HASIL DAN PEMBAHASAN}

Dalam penelitian yang sejenis tentang anak usia dini, Swick mengungkapkan pentingnya komunikasi dalam membentuk karakter anak usia dini. Menurutnya, keluarga, sekolah, dan masyarakat dapat menggunakan komunikasi untuk memperkuat hubungan mereka. Swick juga mengungkapkan bahwa ketika anak usia dini tumbuh dan berkembang, guru dan orang tua perlu melihat juga komunitas bermain mereka yang akan mengembangkan kepribadian anak usia dini tersebut. Perlu diketahui juga bahwa hubungan masyarakat paling baik diwujudkan melalui penggunaan proses komunikasi yang berfungsi terus menerus serta memperbarui dan memperkaya relasi atau hubungan yan terjalin dengan lingkungan, baik sekolah maupun komunitas (Swick, 2003).

Penelitian tersebut semakin menegaskan tentang proses komunikasi yang penting untuk diperhatikan bagi perkembangan karakter anak usia dini. Hal tersebut juga yang menguatkan urgensitas penelitian ini, sehingga penulis pun melakukan wawancara dan observasi pada sebuah lembaga PAUD bernama X, untuk mengetahui upaya yang dilakukannya dalam membangun komunikasi efektif antara guru dan muridnya. Sebagai bagian dari anak usia dini, tentu guru-guru nya pun memiliki upaya agar komunikasi efektif dapat berjalan sesuai dengan harapan.

Berdasarkan asil penelitian menunjukkan bahwa adanya upaya yang dilakukan dalam membangun komunikasi efektif antara guru dan anak usia dini, penulis menemukan beberapa point sebagai berikut:

(1) Guru PAUD sebagai komunikator harus memiliki karakteristik sabar, rela berkorban, perhatian, tegas, serta mampu menarik atensi anak usia dini ND, informan pertama menyampaikan kepada penulis mengenai upaya yang dilakukannya untuk menarik perhatian murid-muridnya. ND mengaku bahwa dia harus berkorban untuk memisahkan muridnya, jika terjadi pertengkaran. Berikut ini penuturan lengkapnya.

"Saya mah gak apa-apa, kalo ada anak yang mau mukul anak lain, saya langsung pisahin, jadi anak itu yang mukul anak lain akhirnya mukul atau ngegigit ke saya. Gak apa-apa...biarin...daripada dia berantem sama temennya. Mendingan saya yang berkorban, karena sama anak usia dini itu ya seperti ini...hehe..." 
266 Improvement of the Logical Intelligence Through Media Kolak

Pernyataan yang disampaikan oleh ND tadi memberikan point utama tentang karakteristik yang harus dimiliki oleh guru-guru PAUD sebagai profesinya. ND menceritakan bahwa karakteristik utamanya adalah sabar dan rela berkorban. ND juga menegaskan bahwa para guru PAUD diberikan pengarahan untuk tidak mendidik muridnya dengan kekerasan. Seperti halnya disampaikan oleh DR yang menegaskan penuturan ND. Di bawah ini adalah kutipannya.

"Guru PAUD itu emang dikasih arahan supaya gak keras ke anakanak, jadi kami mesti ngajarinnya tanpa ada unsur paksaan dan kekerasan, ya mesti ngasih contoh yang baik. Kenapa? Karena kami kan guru, jadi ya mesti perhatian ke anak-anaknya, bener...rela berkorban dan sabar juga tentunya."

Pernyataan yang kedua dari informan ND juga menegaskan tentang pentingnya karakteristik yang harus dimiliki oleh guru PAUD sebagai komunikator. Dalam hal ini, guru PAUD yang akan menjadi contoh di sekolah bagi anak usia dini, perilakunya tentu akan menjadi panutan. Oleh karena itu, adanya karakteristik komunikator, dalam hal ini para guru PAUD merupakan upaya pertama dalam membangun komunikasi yang efektif antara guru dan muridnya.

Informan

lainnya,

$\mathrm{LN}$ menyampaikan pendapatnya tentang karakteristik guru PAUD. Menurutnya, sebagai guru PAUD sudah menjadi tantangan tersendiri untuk tetap bersikap sabar tetapi tegas di depan para muridnya. LN memiliki pendapat yang berbeda dengan guru lainnya.

"Tegas itu penting menurut saya, karena dengan tegas lah anakanak bakal ngerti dan nurut kalo diberitau. Bukannya judes, tapi saya pengen anak-anak paham, jadi kalo saya yang ngasih tau, ada beberapa anak yang emang nurutnya cuman sama saya, katanya karena saya judes, padahal bukan judes, tapi biar mereka pada nurut gitu maksudnya."

Berbeda dengan beberapa informan sebelumnya, penulis melihat jika LN ingin menunjukkan karakteristik tegas sebagai guru PAUD, yang bertujuan agar para murid dapat mengikuti peraturan atau mendengarkan nasihat gurunya. Pernyataan tersebut juga memperlihatkan bahwa sebagai guru PAUD, selain sifat sabar yang harus dimiliki, sikap tegas juga penting sewaktu-waktu, untuk membentuk karakter anak usia dini agar belajar disiplin sejak masih sekolah di lembaga PAUD.

(2) Adanya media/ alat yang digunakan guru PAUD di lembaga $X$ tersebut untuk mencapai komunikasi efektif bagi guru dan anak usia dini

Upaya kedua yang dilakukan para guru PAUD di lembaga $\mathrm{X}$ adalah menggunakan media/ alat sebagai sarana komunikasi untuk mencapai tujuan yang diharapkan oleh para guru tersebut. NF menceritakan bahwa sebagai upaya dalam membangun komunikasi yang efektif, maka para guru sepakat untuk mengoptimalkan peran media komunikasi yang mudah menarik perhatian para muridnya. Hal inipun menyesuaikan karakteristik anak usia dini tersebut. Berikut ini adalah penuturan singkatnya.

"Kami para guru memang diberikan pelatihan juga ya, dalam pendidikan PAUD tuh, ya tentu ga sama kayak di SD, SMP, apalagi jenjang yang lebih tinggi lainnya. Justru kami harus kreatif, memikirkan supaya anak usia dini pada semangat belajar, disiplin, dan berkarakter tuh kayak gimana, lalu kami juga pake alat atau media bantu gitu, ya misalnya dengan bunyi lonceng sebagai tanda jam masuk sekolah akan dimulai, justru pake media gini tuh lebih gampang dipahami anakanak. Terus, pake media gambar, lebih gampang diinget sama anakanak, banyak ya media lainnya, ini sih contohnya aja..." 
Dalam kutipan di atas, penulis melihat bahwa upaya kedua yang perlu dilakukan adalah menggunakan alat/ media untuk membantu tercapainya komunikasi efektif antara guru dengan muridnya.

\section{(3) Guru PAUD harus memahami karakter murid-muridnya yang beragam}

Langkah yang terakhir adalah adanya upaya guru PAUD dalam memahami karakter murid-muridnya yang beragam. Para guru perlu mengetahui keinginan dari muridnya, sehingga akan lebih mudah untuk mencapai komunikasi yang efektif. Misalnya, DN memberikan contoh bahwa ketika para murid sedang semangat belajar membaca, maka para guru akan membantu sampai selesai. Tetapi jika sebaliknya, guru pun tidak boleh memakasa keinginan anak usia dini sebagai muridnya.

Pada intinya, penulis melihat bahwa dalam membangun komunikasi yang efektif antara guru dan muridnya, sebagai komunikator yang baik, guru harus memiliki karakteristik yang dapat menarik perhatian para muridnya. Selain itu, pesan yang disampaikan pun dapat menggunakan perantara alat/ media yang berkesinambungan, agar tujuan komunikasi yang diinginkan dapat tercapai. Selain itu, para guru juga harus memerhatikan target atau sasaran komunikasinya, yaitu para murid PAUD tersebut. Sebagai anak usia dini, tentu ada tantangan tersendiri untuk mendidik mereka agar memahami pesan yang disampaikan para guru. Bahkan, para informan selalu menyampaikan bahwa memahami anak-anak merupakan tugas mereka, dan para guru pun ditekan untuk tidak mendidik anak dengan kekerasan serta paksaan.

DN menambahkan penuturannya di bawah ini.

"Kami emang ditekan gak boleh mendidik dengan keras, apalagi memarahi anak ya, tapi bukan berarti jadi memanjakan anak. Kami tetap tegas, kalau anak salah, kami beritahu gitu, malahan ada guru di sini yang anak-anak bilang galak, karena judes, padahal maksudnya supaya disegani anakanak, jadi mereka terbiasa untuk belajar disiplin, misalnya buang sampah pada tempatnya, terus kalo menerapkan kebersihan, cuci tangan sebelum makan, dan masih banyak lagi...ya itu semua bagian dari proses belajar yang kami ajarkan kepada anak, oh iya terus kejujuran juga...jadi kami tidak boleh memarahi anak, memaksa harus bisa, kalau dia nya udah mau main, ya silakan...kan namanya juga TK itu taman bermain ya, hehe...anak-anak gak boleh dipaksa dan dikerasin..."

Ungkapan di atas tentu menguatkan hasil penelitian ini tentang adanya upaya membangun komunikasi yang efektif antara guru dengan murid PAUD di lembaga tersebut. Ketika penulis melakukan proses pengamatan atau observasi, penulis melihat adanya implikasi dari media-media yang digunakan oleh para guru. Misalnya, penggunaan media lonceng yang berarti simbol jam masuk kelas akan dimulai. Maka, secara spontan, anak-anak pun berlarian menuju sumber suara lonceng tersebut, serta berbaris di depan pintu masuk kelasnya.

Media lainnya adalah melalui lagu, para informan juga bercerita bahwa mereka menyampaikan pesan moral kepada muridnya melalui lagu-lagu tertentu. Menurutnya, ketika para guru mengajak anak-anak menyanyikan lagu tersebut, maka pesan yang ingin disampaikan lebih cepat dan lebih mudah diterima oleh para murid. Inilah yang menandakan proses komunikasi yang terjalin antara guru dan murid berjalan efektif.

Sebagaimana diungkapkan oleh Wilbur Schramm bahwa yang dimaksud komunikasi efektif yaitu terjadinya kesamaan makna pesan antara komunikator dan komunikan (Mulyana, 
2010). Dalam hal ini, komunikator adalah para guru PAUD dan komunikan adalah para murid sebagai anak usia dini di lembaga tersebut.

\section{PEMBAHASAN}

\section{Teori Interaksi Simbolik}

Penulis melihat bahwa proses komunikasi yang efektif dan terjalin antara guru dan murid PAUD ini sebagai sebuah interaksi yang bermakna. Dalam ilmu komunikasi, ada prinsip komunikasi yang mengatakan "diam pun merupakan pesan yang disampaikan komunikator". Oleh karena itu, dalam bagian ini, penulis melihat teori yang relevan untuk menganalisis penelitian ini, yaitu teori interaksi simbolik.

Menurut Ralph Larossa dan Donald C. Reitzes (Turner, 2008), interaksi simbolik pada intinya menjelaskan tentang kerangka referensi untuk memahami bagaimana manusia berperilaku, bersama dengan orang lain, menciptakan dunia simbolik serta bagaimana cara dunia membentuk perilaku manusia.

Interaksi tersebut yang dimaknai berdasarkan kesepakatan bersama oleh semua pihak yang terlibat dalam suatu interaksi merupakan satu bentuk simbol yang mempunyai arti yang sangat penting. Oleh karena itu, definisi singkat dari tiga ide dasar dari interaksi simbolik diuraikan dalam hal di bawah ini:

\section{a. Mind (pikiran)}

Dalam penelitian ini, kemampuan untuk mengembangkan ide agar tercapainya makna yang sama antara guru dan murid PAUD merupakan bagian dari ide dasar yang pertama, yaitu Mind. Penulis melihat para guru melakukan upaya membangun komunikasi yang efektif, sebagai hasil dari "Mind" mereka.

\section{b. Self (diri pribadi)}

Dalam penelitian ini, penulis melihat adanya kemampuan para guru sebagai informan untuk merefleksikan diri tiap individu dari penilaian sudut pandang atau pendapat orang lain, misalnya para murid PAUD tersebut dapat menilai ada guru yang tegas, baik, sabar, dan lain-lain, dalam artian mengemukakan tentang diri sendiri (the-self) dan dunia luarnya.

\section{c. Society (masyarakat)}

Ini adalah point ketiga yang melihat adanya hubungan sosial yang diciptakan, dibangun, dan dikonstruksikan oleh para guru dan murid ditengah masyarakat, dan tiap individu tersebut terlibat dalam interaksi yang dilakukannya. Interkaasi tersebutlah yang kelak mengantarkan manusia dalam proses pengambilan peran di tengah masyarakatnya. Misalnya, para murid yang dapat menyerap pesan dari berbagai interaksi yang dilakukannya dengan para guru, seperti halnya kejujuran, nilai disiplin, sopan santun, dan lain-lain.

Berdasarkan uraian di atas, penulis melihat kesesuaian teori interaksi simbolik dalam penelitian ini, karena membahas tentang interaksi dan adanya pertukaran makna yang disepakati antara para guru dan murid PAUD tersebut. Contoh lainnya, pertukaran makna yang berupa simbol tersebut adalah ketika guru membunyikan lonceng sebagai simbol tanda masuk sekolah, maka para murid pun berlarian menuju sumber suara dan berbaris di depan kelas. Ini bagian dari pembelajaran adanya interaksi yang terjalin, para murid pun memahami makna pesan dari simbol lonceng tersebut.

Pada intinya, penulis pun dapat menemukan bahwa proses komunikasi dapat terjalin dengan baik di lembaga PAUD sekalipun. Ketika para guru mampu berupaya membangun komunikasi yang efektif dengan para muridnya, maka tujuan dari proses komunikasi tersebut dapat tercapai sesuai dengan harapan.

Senada dengan pernyataan diatas, hasil penelitian (Ersay, 2015) didapatkan "This happens as a result of the upbringing which children receive from their family, 
schools and community" were "because the family, schools and community all give children with an ability in science the encouragement and opportunity to become scientists" and "it is difficult to tell". Orang tua, sekolah dan masyarakat secara bersama-sama memberikan dorongan dan kesempatan kepada anak untuk menjadi ilmuwan.

\section{SIMPULAN}

Berdasarkan hasil penelitian yang telah dilakukan, penulis melihat bahwa adanya upaya yang dilakukan dalam membangun komunikasi efektif antara guru dan anak usia dini, meliputi: (1) guru PAUD sebagai komunikator harus memiliki karakteristik sabar, rela berkorban, perhatian, tegas, serta mampu menarik atensi anak usia dini; (2) adanya media/ alat yang digunakan guru PAUD di lembaga $\mathrm{X}$ tersebut untuk mencapai komunikasi efektif bagi guru dan anak usia dini; (3) guru PAUD harus memahami karakter murid-muridnya yang beragam.

Pada intinya, setiap aktor atau peran yang terlibat dalam proses komunikasi tersebut harus saling berkoordinasi agar tujuan komunikasi yang diinginkan dapat tercapai. Misalnya, penulis melihat adanya kerjasama antar para guru, mereka membagi peran masingmasing, khususnya dalam menangani para muridnya, sehingga komunikasi yang dilakukan pun berjalan efektif.

\section{UCAPAN TERIMA KASIH}

Dengan terbitnya artikel ini, penulis ingin mengucapkan terimakasih yang setulusnya kepada semua pihak yang telah membantu dalam proses penelitian ini. Ucapan terimakasih yang terutama ingin disampaikan kepada para informan yang telah berkenan dalam berdiskusi dengan penulis, serta pihak lainnya yang telah berkontribusi dalam penulisan artikel ini.

\section{DAFTAR PUSTAKA}

Aprinawati, I. (2017). Penggunaan Media Gambar Seri Untuk Meningkatkan Kemampuan Berbicara Anak Usia Dini. Obsesi, Pendidikan Anak Usia
Dini, 1(1), 72-80.

Aulina, C. N. (2018). Penerapan Metode Whole Brain Teaching dalam Meningkatkan Motivasi Belajar Anak Usia Dini, 2(1), 1-12.

Creswell, J. W. (2010). (2010). Research Design: Pendekatan Kualitatif, Kuantitatif, dan Mixed. Yogjakarta: PT Pustaka Pelajar.

Ersay, E. (2015). Investigating PreService Early Childhood Teachers' Views on Science Technology and Society Issues in Turkey. Procedia Social and Behavioral Sciences, 191, 1397-1402.

https://doi.org/10.1016/j.sbspro.2015. 04.318

Mulyana, D. (2010). Pengantar Ilmu Komunikasi (p. 33). Bandung: PT Remaja Rosdakarya.

Prasanti, Ditha \& Fitriani, D. R. (2018). Pembentukan Karakter Anak Usia Dini: Keluarga, Sekolah, dan Komunitas? Obsesi, 1(2).

Swick, K. J. (2003). Communication concepts for strengthening familyschool- community partnerships. Early Childhood Education Journal, 30(4), 275-279.

West, T. (2008). "Pengantar Teori Komunikasi Analisis dan Aplikasi". Jakarta: Salemba Humanika.

White, E. J., Peter, M., \& Redder, B. (2015). Infant and teacher dialogue in education and care: A pedagogical imperative. Early Childhood Research Quarterly, 30(PA), 160173. https://doi.org/10.1016/j.ecresq.2014. 10.008

Yus, A. (2011). Model Pendidikan Anak Usia Dini. Jakarta: Prenada Media Group. 